\title{
Java Man and the Politics of Natural History
}

\section{An Object Biography}

\author{
Caroline Drieënhuizen | ORCID: 0000-0002-5719-2328 \\ Open University of the Netherlands, Heerlen, the Netherlands \\ caroline.drieenhuizen@ou.nl
}

Fenneke Sysling | ORCID: 0000-0001-8097-1568

Leiden University, Leiden, the Netherlands

f.h.sysling@hum.leidenuniv.nl

\begin{abstract}
Natural history museums have long escaped postcolonial or decolonial scrutiny; their specimens were and are usually presented as part of the natural world, containing only biological or geological information. However, their collections, like those of other museums, are rooted in colonial practices and thinking. In this article, we sketch a political and decolonial biography of 'Java Man', the fossilized remains of a Homo erectus specimen, housed in Naturalis, the Natural History Museum, in the Netherlands. We describe the context of Dutch colonialism and the role of indigenous knowledge and activity in the discovery of Java Man. We also follow Java Man to the Netherlands, where it became a contested specimen and part of a discussion about repatriation. This article argues that the fossils of Java Man and their meanings are products of 'creolized' knowledge systems produced by Empire and sites of competing national and disciplinary histories and identities.
\end{abstract}

\section{Keywords}

natural history museums - Java Man - repatriation - object biography 


\section{Introduction}

Natural history museums have long escaped postcolonial or decolonial scrutiny and are only now somewhat hesitantly joining the conversation about the role of non-Western objects in Western museums that has hitherto focused on ethnological and art museums. Specimens in natural history museums were and are usually presented as part of the natural world, containing only biological or geological information.

As in other museums, however, the collection histories and the museum presentation of many natural history collections are firmly rooted in colonial practices and thinking. As historians of natural history have shown, the pursuit of natural history was built upon information-knowledge and specimensgathered from colonial contexts. Natural history also drove imperialism, because it contributed to building the narrative that conquest was necessary and would be profitable (Brown 1996; Drayton 200o). As Nicholas B. Dirks put it, in a wider context 'colonial knowledge both enabled conquest and was produced by it' (Dirks 1996:ix). These colonial narratives were also institutionalized in museum displays (Haraway 1984; Carnall, Ashby and Ross 2013; Das and Lowe 2018).

In the mid 1990s, scholars such as Dirks and Bernhard Cohn related this kind of knowledge to colonial state power in the Foucauldian sense (Cohn 1996; Dirks 2001). Since then, however, historians have moved away from the state-knowledge nexus and argue for a more complex understanding of the actual process of this production of knowledge, the role of indigenous agents and informants, and the significance of local knowledge in the formation of scientific knowledge and heritage. ${ }^{1}$ For colonial and postcolonial Indonesia, Martijn Eickhoff and Marieke Bloembergen, for example, have argued that even though heritage sites and objects and their accompanying knowledge production were tools for colonial and postcolonial nation-building, they also 'accommodated alternative imaginations' (Bloembergen and Eickhoff 2011:409). They therefore propose to follow heritage sites and site-related objects over space and time, to be able to trace the various encounters and meaning-making that took place around them, and the changes and continuities between colonial and postcolonial regimes (Bloembergen and Eickhoff 2020).

1 See, for example, Baber 1996; Chambers and Gillespie 200o; Watson-Verran and Turnbull 1995; Schumaker 2001; and Wagoner 2003. For natural history, see Pols 2009 and Montero Sobrevilla 2018; see also http://www.nhm.ac.uk/discover/slavery-and-the-natural-world.html (accessed 3-2-2021). 
A similarly fruitful way to show the stories that the natural museums have omitted in their presentation of specimens is, we believe, to present object biographies of natural history objects. Igor Kopytoff and Arjun Appadurai claim that objects can only be understood relationally: as a whole of processes of production, exchange, and consumption, including the persons and events involved. Only then can underlying structures and assumptions be laid bare (Appadurai 1986; Kopytoff 1986). Several studies have shown this to be a very valuable approach when applied to objects with a colonial history, whose lives usually include at least one major transition from a non-Western context to a Western museum setting. ${ }^{2}$

In this article, we apply a biographical approach to Java Man-the skullcap, molar, and thighbone of a Homo erectus - who is housed in Naturalis, the Natural History Museum in Leiden, the Netherlands, where he is one of the centrepieces. The Java Man fossils were discovered in Dutch colonial Indonesia in 1891 and 1892, in an excavation led by Eugène Dubois (1858-1940). Dubois, a Dutch medical doctor and anatomist with an interest in fossils and evolution, shot to fame with this find and his identification of the fossils as a human ancestor, and spent the rest of his life studying his fossil collection (Theunissen 1989; Shipman 2001). At the time, Dubois named the bones Pithecanthropus erectus, 'upright going ape-man'; today the bones are considered a Homo erectus specimen. Importantly, for over three decades, Java Man was the oldest human specimen that was ever found. It was not until the 1920s that more ancestors were added to the phylogenetic tree of mankind after finds were made in South Africa (the Taung child), and in China (Peking Man): Java Man was no longer the sole specimen of its kind.

The fact that Java Man and most other humanoid fossils are in a natural history museum today is the result of nineteenth-century discipline formation in these museums. Many colonial expeditions returned with diverse sets of objects, varying from art works and prepared birds to human remains. Over the years, these objects were separated, with the ethnographical objects going to ethnographic museums and the natural objects going to the Natural History Museum. Fossilized humanoid remains such as Java Man, possibly over a million years old, became part of a collection used to study evolution at natural history museums, while human remains of more recent date were seen as better off in collections with a medical anthropological focus such as the Anatomical Museum of Leiden University (Sysling 2016). As a result, some of the mutual

2 Legêne 1998; Gosden and Marshall 1999; Alberti 2005; Dahlbom 2009; Bloembergen and Eickhoff 2020 . 
colonial history of these collections has been lost. Not all of the scholarship and debate about human remains collected in colonized regions is applicable to fossils too- the Java Man fossils are not someone's recent ancestor, nor has the living individual of which they are the remains (if it was one individual) suffered under the colonial regime. Both categories, however, have a cultural and political significance, in addition to their biological characteristics, that many museums are hesitant to research and discuss.

A biography of Java Man could consist of many possible storylines. In this article, we focus less on the way these bones have been given meaning in discussions on, and changing notions of, evolution, the missing link, apes, and men, because these aspects of Java Man are already well documented (Theunissen 1989; Shipman 2001). We also pay relatively little attention to their life on display (the fossils have only been on permanent display in the Leiden museum since 1998). Often overlooked, however, is the fact that after Indonesian independence, Java Man became a contested object in a discussion about repatriation that started in the 195os and only decreased in intensity at the end of the 1970s. We therefore sketch a biography of Java Man in which we show the continuing processes of signification and appropriation, both from the Dutch and from the Indonesian side.

In the following sections, we first describe the context of Dutch colonialism and the role of local knowledge and indigenous palaeontological activity in the eventual discovery of Java Man and related hominid fossils. We then follow Java Man to the Netherlands, where it became a museum object claimed by Indonesia and defended by the Leiden Natural History Museum. We show how both the Dutch and the Indonesians incorporated Java Man into their narratives: the Dutch emphasized that they were both the discoverers of the specimens and, as a European museum, the detached guardians that could safeguard them for the rest of the world. For the Indonesians, Java Man was important to their national and scientific culture.

In this article, we problematize the histories of collecting and knowledge production that emerged in Europe, to undo what Aníbal Quijano calls the 'coloniality of knowledge' (Quijano 2007:168-78) and to move the conversation to include natural history collections and museums. With our focus on the provenance of Java Man, the long-contested political ownership of these fossilized remains, and the meanings attached to them in the Netherlands and in Indonesia, we show how they are sites of competing national, disciplinary, and local histories and identities. 
According to Indonesian palaeontologist Teuku Jacob (1929-2007), the history of human-fossil excavation in Indonesia can be divided into three phases: that led by Eugène Dubois in the late nineteenth century; that of the Geologische Dienst (Geological Survey, established in 1922) in the 1930s; and an Indonesian phase after independence (Jacob 1973). These phases can also be linked to where the fossils ended up: those of the first period are in Leiden; those of the second were (and to some extent still are; see below) in Frankfurt, where Ralph von Koenigswald (1902-1982), the palaeontological specialist for the Dutch Geological Survey, moved his collection; and those of the third phase are in Indonesia.

Dubois started searching for fossils on the island of Sumatra. His interest in palaeontology, combined with the suggestion of the influential German evolutionist Ernst Haeckel that tropical Asia may have been the birthplace of mankind, prompted Dubois to join the Dutch Indies army. This enabled him to go on fossil-hunting expeditions every now and then in addition to fulfilling his medical duties. In an article that was also a call for more funding and governmental support, he described the Indies as a virgin territory that held great promise, and he appealed to feelings of national prestige before warning that it would not take long before foreign scholars would also turn their attention to this region (Dubois 1889; Theunissen 1989:38). The article was successful and made it possible for Dubois to extend his research. When his Sumatra finds turned out to be disappointing, he moved to Central Java, where earlier scholars had reported promising mammal fossil finds. There, at the Trinil site, the three fossils were found that Dubois attributed to a man-ape, and later to an ape-man.

In the 1930s, Berlin-born archaeologist Ralph von Koenigswald continued Dubois's work when he joined the Geological Survey of the Netherlands Indies. The Survey excavated the so-called Ngandong skulls and the Mojokerto child on the island of Java, all known today as Homo erectus fossils. It was only in the context of Dutch colonialism, then, that Dubois and Von Koenigswald were able to carry out their searches: Dutch colonial authorities provided them with a job, the opportunity to conduct scientific research, and the forced labourers to do the heavy work.

These forced labourers, with their trained Indonesian supervisors (mantri), brought the finds to the Western scientists sitting in their offices in a nearby city or, in the case of Dubois, at home: he was not up to living in the forest in an improvised hut. ${ }^{3}$ The Mojokerto skull was found by mantri Andoyo (later

3 Letter from E. Dubois to F.A. Jentink, 17-10-1889, cited in Theunissen 1989:40. See also Albers and De Vos 2009:9 and Huffman et al. 2010:5. 
Cokrohandoyo), an experienced geological assistant with technical skills, and identified by Von Koenigswald as early hominin (Huffman et al. 2005). For collecting, Von Koenigswald also depended on Atma, whom he had 'discovered' (as he put it) when Atma was working as a gardener. When there was no money, Atma cooked for Von Koenigswald and did his laundry (Von Koenigswald 1956:83).

Both Dubois and Von Koenigswald could only do their work thanks to the efforts of forced labourers but also of the local population and of earlier scholars with an interest in Javanese fossils. One of these earlier scholars was the famous Javanese painter and autodidact Raden Saleh (1807-1880), who received his art education in the Netherlands and had scientific and scholarly interests. When Raden Saleh returned to Java and travelled the island as part of an art tour, he conducted several excavations in which he found fossil mammals. At one dig, he was supported by the son of the patih (chief minister) of Yogyakarta, which shows there was some interests in these finds among the Javanese elite (Kraus 2012:88).

In 1866, Raden Saleh travelled to the area of Gunung Pandan. As his biographer Werner Kraus reports, Raden Saleh may have discovered a good fossil spot there thanks to an earlier book by Javanese traveller Raden Mas Tjondronegoro $\mathrm{V}$, the later regent of Kudus and Brebes. Tjondronegoro wrote how in a village near the Pandan mountain he was shown bones of unusual size that locals attributed to the giant of Arimba, who was killed by the heroes of the Mahabharata (Poerwolelono 2013 [1877]:206; Kraus 2012:86-9). Tjondronegoro himself, an educated aristocrat, did not believe those local legends anymore. According to him, the bones belonged to large animals that were mentioned in age-old stories but that did not exist anymore (Poerwolelono 2013 [1877]:207). As Raden Saleh had promised the Bataviaasch Genootschap van Kunsten en Wetenschappen (Batavian Society of Arts and Sciences), of which he and Tjondronegoro were one of few Javanese members, he sent the bones to the Society, after which they ended up in the Natural History Museum in Leiden (Raden Saleh 1867:422-3, 426-9, 433-7, 448-51, and 455-9).

Like Raden Saleh, Dubois, and later Von Koenigswald, could not have done their work without the directions of the local population. The local population in Central Java was well aware of large and odd-shaped bones found in their paddies and surroundings. As they told European scholars around 190o, they called them balung buto or tulang raksasa (giants' bones) and considered them to be the bones of giants that once battled against each other. ${ }^{4}$ The pop-

4 'De Selenka expeditie', De Sumatra Post, 14-7-1908. For a comparable case in India, see Van der Geer, Dermitzakis and De Vos 2008:71-92. 
ulation believed (and still do) that these bones of their ancestors had healing qualities, and they used them as talismans (Sulistyanto 2003; Handini 2015). An Indonesian booklet produced by the paleontological Sangiran Museum in 2010 argues that in fact 'the legend of the mythical Great War [of the Mahabharata] had been able to direct the researchers towards their great discoveries', thereby countering the Eurocentric scientific perspective (Widianto and Simanjuntak 2010:111).

Von Koenigswald also relied on Chinese pharmacists in Batavia (nowadays Jakarta) who sold fossils as medicines, and he used the local population in Sangiran to find fossils. To encourage them to bring in fossils, he paid them one cent or half a cent for an ordinary tooth and ten cents for skull fragments (Von Koenigswald 1956:52-4, 96 and Sulistyanto 2009). The Sangiran people continued to use their skills in identifying fossils after Indonesian independence: Teuku Jacob mentioned that Sangiran was a promising site but presented special problems, because thanks to these local collectors, prices of fossils were much higher than at other sites (Jacob 1973:476).

In their letters and publications about the excavations, Dubois, Von Koenigswald, and other scientists described these people-on whom they heavily depended —only in passing or very judgementally (Von Koenigswald 1956:524). In their research notes, Von Koenigswald and his colleague W.F. Oppenoorth (1881-1965) mention their mantri Samsi and Panudju during the 1931-1936 excavations just in passing: 'young natives, who had been in training to become mantris' (Sulistyanto 2009:57-80, especially 64; Von Koenigswald 1956:96; see also Huffman et al. 2010:22). Dubois was less matter of fact. The letters he wrote to his two European sergeants overseeing the 1889 excavation are full of complaints. His workers were 'indolent as frogs in winter' during the month of fasting, were often insubordinate, 'concealed' finds from him, and bribed their overseers. Furthermore, the forced labourers ran away, were ill, and misbehaved. ${ }^{5}$ Von Koenigswald also complained about his 'commercial brown friends' in Sangiran breaking large fossils into smaller pieces because they received money for every part they brought to him (Von Koenigswald 1956:97). Jacob later mentioned the same problem and added that local people did not always report the exact finding spots for fear of losing their potential sources of income (Jacob 1973:476). This reveals how Indonesian science inherited certain colonial practices but without the colonial worldview Dubois expressed.

5 Letter from E. Dubois to F.A. Jentink, 17-10-1889, cited in Theunissen 1989:40. 
Dubois's writing here shows a 'colonial gaze' (Pratt 1992) — the colonial superior observing the colonized without any concern for their situation and without any danger of reciprocity, given the asymmetric relation of power. Many Western writings today still focus on the Dutch protagonists of the story and continue the silence on the pivotal role of local informants and scholars in the discovery of Java Man and other fossils. It shows how the story of the discovery of the fossil was adapted for a Western readership, a story in which Java Man came to be featured as a Dutch national scientific trophy.

\section{3}

Java Man and Indonesia's National Narrative

When Eugène Dubois returned to the Netherlands in 1895, he took the Java Man fossils with him as his personal possession. He kept the fossils in a safe at the Teylers Museum in Haarlem, where he had become a curator, but became very protective of them, refusing his colleagues access to the fossils for many years. They later moved to Leiden (Shipman 2001). There, the fossils became contested objects after the transfer of sovereignty from the Netherlands to Indonesia in 1949. The question of the restitution of cultural objects was raised during the Round Table Conference in the summer and autumn of 1949 at which the two countries reached agreement on sovereignty. A draft cultural agreement was signed that included an article stipulating the return of cultural objects (Legêne and Postel-Coster 200o; Van Beurden 2017:144-9; Drieënhuizen 2018). Among themselves, Dutch officials thought repatriation could be undertaken as a goodwill gesture that would improve the Netherlands' public image and also allow the Dutch to maintain a cultural presence in Indonesia (Scott 2017, 650-1; Scott 2019).

The issue of restitution of cultural objects was pressed above all by Muhammad Yamin, Member of Parliament and later minister of education and culture of the Indonesian Republic. In 1951, Yamin pointed to the great number of objects of invaluable scientific and cultural importance for Indonesia that remained overseas. Among the objects that, according to Yamin, should be returned to Indonesia 'in the interest of the Indonesian nation and its people' were several fossilized skulls and human remains found in Java by Eugène Dubois. $^{6}$

6 Aneta morning bulletin, 2-4-1951, National Archives of the Netherlands (NA), The Hague, Archief van het Ministerie van Koloniën en opvolgers (Archive of the Ministry of Colonies and its Successors) 2.10.54, 1684. See also 'Eis tot teruggave cultuurgoederen', Algemeen Indisch Dagblad: De Preangerbode, 17-3-1954. 
Yamin was an important figure in the postcolonial attempt to build up the new nation by mobilizing and uniting Indonesians behind new narratives. This was a challenge, since Indonesia was a typical product of colonialism and had not in fact existed as a unified region before the arrival of the Dutch. Yamin's new national history for Indonesia emphasized the greatness of Indonesia in precolonial times and minimized the influence of colonial rule. According to Henk Schulte Nordholt, Yamin was 'the main architect' of this new narrative of Indonesia's past. ${ }^{7}$ By insisting on the repatriation of historical and cultural objects, Yamin and his compatriots resisted the Dutch version of the past and claimed and appropriated a new historical perspective (see also Lyons 2002:116).

The Java Man fossils fit neatly into this new national (Java-centred) narrative of pre-colonial domestic greatness. The fossils were considered highly important for the new nation state, as they served as scientific proof that Java was the oldest island in the world and the place where the origins of mankind could be localized. Objects such as the fossils highlighted the precolonial past and Indonesia's importance for the world.

Yamin's other argument for claiming the fossils had to do with the importance of the pursuit of science in Indonesia. In addition to being cultural objects, Yamin pointed out, they were 'priceless for the prehistorical and anthropological sciences' and were crucial for higher education and scientific study in Indonesia. ${ }^{8}$ After independence, Indonesia faced the task of educating a new generation of students and rebuilding the scientific institutions that had been left depleted with the departure of the Dutch and after years of revolution (see, for example, Pols 2018). The fossils - found in colonial Indonesia by local workers supervised by Western scientists, and brought to Europe as the discovery of those Western scientists - symbolized a scientific imperialism that impeded scientific progress in Indonesia and that was fiercely condemned by Yamin.

The role of the politician Yamin shows that the restitution claims in the aftermath of Indonesia's independence should be understood as a political act: the restitution of objects was considered a step towards the recognition of Indonesia as an independent and equal nation with a definite, distinct, and deep-seated history and identification. By stressing the importance of restitution, Yamin invested the claimed objects with historical and political associations that would inspire the national historical imagination and turn them into national symbols and 'the essence of the nation': its cultural patrimony

7 Schulte Nordholt 2004:3. See also Van der Kroef 1958:352-71, especially 353; Noer 1979:249-62; Wood 2005; Bloembergen and Eickhoff 2011:405-36, especially 407.

8 Aneta morning bulletin, 2-4-1951, NA, 2.10.54, 1684. 
(Barkan 2002:22). This need of Indonesia to assert its political and social identity through these narratives of ownership was something that the Netherlands was unable or unwilling to understand. Dutch officials, perhaps unsurprisingly, found Yamin's statement 'unsympathetic' and 'provocative.' 9

The Dutch stand was not very different from that of other imperial countries, although we are not aware of other humanoid fossils that were found before independence, taken to the West and claimed so soon after. Broken Hill Man was found in 1921 in (then) Rhodesia and has been claimed by Zambia from the Natural History Museum in London, but this was more recently (Musonda 2013; see also Staniforth 2009). When Peking Man was discovered in 1923-1927, agreements were made between Western scientists and the Chinese government that all fossils would remain in Chinese ownership (Schmalzer 2008).

The Dutch reluctance to hand over the objects, and the fact that in the 1950s Dutch academics continued to scour Indonesia for fossils, ${ }^{10}$ confirmed Indonesia's opinion of the Netherlands' undiminished cultural imperialism. The Dutch, on the other hand, clung to the idea of the universality of science while at the same time considering science 'a uniquely European product' (Somsen 2008:361). The Netherlands and Indonesia were unable to come to a mutual understanding on the complete agreement of 1949, and in 1954 it was terminated. The fossils, in this period, had become more and more politicized, drawn into postcolonial power struggles brought about by differing conceptions about what decolonization actually entailed.

\section{Java Man as Universal Scientific Heritage}

Although in the Netherlands people gradually became more critical of the Dutch colonial past, in the 1970s the return of Indonesian objects remained a controversial topic in political debates. After several years of no communication, 1968 saw the signing of a cultural treaty between the Netherlands and Indonesia that included a clause opening the door for 'consultations'

9 Letter from the Department of Communications of the High Commissioner in Indonesia, to Ministry of Union Affairs and the Overseas Territories, The Hague, 16-4-1951, NA, Archive of the Ministry of Colonies and its Successors 2.10.54, 1684.

10 See, for example, a letter from a geologist in Bandung to G.H.R. von Koenigswald, warning him that Indonesians were increasingly hostile towards Western researchers. Letter from a geologist in Bandung to G.H.R. von Koenigswald, 23-10-1952, Senckenberg Forschungsinstitut und Naturmuseum Frankfurt (Senckenberg Research Institute and Natural History Museum Frankfurt) Von Koenigswald Archive. 
about Indonesian cultural objects in the Netherlands. Pressure from Indonesia ensured that the question remained on the Dutch agenda during the 197os. In the early years of that decade, as Cynthia Scott has shown, there was a 'markedly concerted effort by Indonesian officials to press the matter in the media and at meetings with Dutch foreign ministry and cultural officials' (Scott 2017:662). With respect to cultural objects this had some success: in 1970, the palm-leaf manuscript Nāgarakrtāgama was returned to President Soeharto of Indonesia on the occasion of a visit to the Netherlands. A Dutch-Indonesian meeting to discuss the issue of the repatriation of cultural objects was held in Indonesia in 1975 and led to an agreement in which the Dutch declared their willingness to return such items. As a result, in 1978, the Buddhist statue Prajñāpāramitā was presented to the Museum Nasional Indonesia (National Museum of Indonesia) in Jakarta on its bicentennial anniversary. While Indonesians spoke of the 'return' of these cultural objects, the Dutch insisted on using the word 'transfer'."1

With regard to the Dubois collection, all that was announced was an investigation into its ownership (Van Beurden 2017:114-5). The claim for the fossils' return had its own spokesperson in Teuku Jacob. ${ }^{12}$ Jacob was the most important Indonesian palaeontologist of his generation, and he had received his education in the Netherlands. He had completed a PhD in Utrecht with Von Koenigswald and was now a professor at the Universitas Gadjah Mada (UGM, Gadjah Mada University) in Indonesia and dean of the Faculty of Medicine. In the 1980s, he would become the rector of UGM. ${ }^{13}$ In Jacob's research, he situated Dubois in a narrative that led to independent Indonesian palaeontology: Dubois's finds were seen as the first phase of the discipline's development (Jacob 1973). In relation to possible repatriation he, like Yamin, argued that the bones were of great value for academic research in Indonesia. Perhaps because this argument was the most important to him as a researcher, he made no reference to the ancient Javanese past or the greatness of Indonesia, as Yamin did.

11 Bloembergen and Eickhoff 2015:53; Van Beurden 2017:144-9; see also Report of the Dutch delegation regarding cultural collaboration between Indonesia and the Netherlands, 10 to 22 November 1975, NA, Archieven van de Ministeries voor Algemeene Oorlogvoering van het Koninkrijk, en van Algemene Zaken (AZ): Kabinet van de Minister-president (archives of the Ministries of War and of General Affairs, Cabinet of the Prime Minister) 2.03.01, 9221. Associated Press article, no date, NA, Archief van het Ministerie van Cultuur, Recreatie en Maatschappelijk Werk (Archive of the Ministry of Culture, Recreation and Social Work) 2.27.19, 1425. See also 'Indonesië: Aapmens terug', Haagsche Courant, 17-9-1977, copy in NA, 2.27.19, 1425 and 'Indonesië wil van Nederland beenderen aapmens terug', Leeuwarder Courant, 17-8-1977, p. 35 .

'Obituary: Influential paleontologist T. Jacob dies at 77', The Jakarta Post, 19-10-2007. 
While in the 1950s the voices had come mainly from the Indonesian side, this time the director of the Natural History Museum in Leiden, Willem Vervoort, made sure his own counterarguments were heard. In the Dutch press Vervoort called the Indonesian claims 'madness', ${ }^{14}$ and said that 'if we start to return scientific finds, we might as well organize a sale. ${ }^{15} \mathrm{He}$ also sent concerned and emotional letters to the Dutch Ministry of Culture, Recreation and Social Work when he was informed of Indonesia's claims, saying that he would do his utmost to counter the proposed 'mutilation of his institute', to make sure these fossils would stay at the museum, where they belonged, both legally and scientifically. ${ }^{16}$ From Vervoort's point of view the fossilized remains had been obtained legally and were thus the rightful property of the Dutch state.

The Dutch state itself was not so sure that the remains legally belonged in the Netherlands. Already in the 193os there had been a dispute about whether the fossils were owned by the Dutch state or by the colonial government in Batavia. In 1931, Head of the Geological Survey of the Netherlands Indies A.C. de Jongh argued that the Dubois collection belonged in the Indies, because Dubois had been employed by the colonial government. The question of why the collection was not in the Indies was then also posed in the colonial advisory body, the Volksraad (People's Council), but the question was never answered satisfactorily. ${ }^{17}$

After the 1975 Dutch-Indonesian meeting, the question of legal ownership again caused headaches for Dutch civil servants and lawyers, as can be concluded from the numerous memorandums on exactly that question. Now they also discussed whether the agreements related to the transfer of sovereignty included any relevant provisions, and whether international treaties applied, such as the Unesco treaty of 1970 on the protection of cultural property. ${ }^{18}$ Offi-

14 'Bericht in Leiden met verbijstering ontvangen. Indonesië: Aapmens terug', Haagse Courant, 17-9-1977.

15 'Indonesische professor eist pronkstuk van Leids museum op', De Telegraaf, 20-9-1977, p. 5.

16 Letter of W. Vervoort to R. Hotke, director-general of the Ministry of Culture, Recreation and Social Work, Leiden, 2-3-1976, NA, Archive of the Ministry of Culture, Recreation, and Social Work, Deliberations between the Netherlands and Indonesia on the collection M.E.F.T. Dubois, 1977-1979, 2.27.19, 1425 .

17 A.C. de Jongh, 'De collectie-Dubois', N.R.C. 13-1-1931, copy in NA, 2.27.19, 1425; letter from the Minister of Colonies to the Minister of Education, Art and Science, NA, 2.27.19, 1425; 'Collectie Dubois en het Geologisch Museum Bandoeng', De Locomotief, 6-2-1931 and 'De collectie-Dubois blijft toch in Holland. Ofschoon ten onrechte', De Locomotief, 24-31932.

18 E. Hartkamp-Jonxis, 'Enige kanttekeningen bij de wijze van verwerving, overbrenging naar Nederland, plaatsing en eigendom van de collectie-Dubois', 23-6-1977, NA, Archive of the 
cials concluded that even if it was the case that the Dutch state was 'not or not completely' the rightful owner of the fossils, it was likely that the rights of 'others' could also not be proven and the case was already time-barred. ${ }^{19}$

The Natural History Museum also argued that the remains belonged in the Netherlands scientifically: they could serve the international scientific community better from there than from elsewhere, because the institution was well known internationally. This was and still is an often-heard argument from Western museums, best known from the British Museum's position on Greece's calls for the repatriation of the Parthenon Marbles (Greenfield 2007:41-96). Vervoort, the director of the museum, apparently did not consider Indonesian scientists as part of that international community. ${ }^{20} \mathrm{He}$ added that if the fossils were 'ceded' to Indonesia, 'this very valuable material will in fact no longer be used scientifically'.21 Among the resources that Leiden had and Yogyakarta or Bandung did not, he suggested, were facilities for photography and plastercasting, and X-ray equipment. ${ }^{22}$ Another argument Vervoort adduced was that Indonesia had a very good collection of fossils itself.

A further line of reasoning was based on a narrative that separated scientific from cultural heritage. Vervoort argued that the fossils in the Dubois collection had nothing to do with the Dutch colonial past. ${ }^{23}$ Scientific heritage, he wrote, should not be discussed with emotional and nationalistic arguments, but only with detached scientific interest. According to him, the issue had become a 'question of sentiment' in Indonesia. ${ }^{24}$ However, he argued, emotional arguments that were valid for ethnographical objects did not hold for

Ministry of Culture, Recreation, and Social Work, 2.27.19, 1425; Memo W.A. Panis to head consultant for museums, no date, NA, Archive of the Ministry of Culture, Recreation, and Social Work, 2.27.19, 1425 .

19 E. Hartkamp-Jonxis, 'Enige kanttekeningen bij de wijze van verwerving, overbrenging naar Nederland, plaatsing en eigendom van de collectie-Dubois', 23-6-1977, NA, Archive of the Ministry of Culture, Recreation, and Social Work, 2.27.19, 1425.

20 Short memorandum on the meaning of the skulls of Pithecanthropus and Wadjak, 12-21976, Archive of the Ministry of Culture, Recreation, and Social Work, 2.27.19, 1425.

21 Confidential letter from W. Vervoort, director of the Rijksmuseum Natuurlijke Historie, to R. Hotke, director-general of the Ministry of Culture, Recreation and Social Work, 2-3-1976, NA, Archive of the Ministry of Culture, Recreation, and Social Work, 2.27.19, 1425 . W. Vervoort, Aide-mémoire concerning the Dubois collection and the remains of the ancestors of mankind (Pithecanthropus and Wadjak) in that collection, NA, Archive of the Ministry of Culture, Recreation, and Social Work, 2.27.19, 1425.

23 Confidential letter from W. Vervoort, director of the Natural History Museum in Leiden to R. Hotke, director-general of the Ministry of Culture, Recreation and Social Work, 2-3-1976, NA, Archive of the Ministry of Culture, Recreation, and Social Work, 2.27.19, 1425.

24 'Indonesië: Aapmens terug', Haagsche Courant, 17-9-1977, copy in NA, Archive of the Ministry of Culture, Recreation, and Social Work, 2.27.19, 1425 . 
fossils. ${ }^{25}$ Historians of science have by now shown repeatedly that such insistence on the detached objectivity of scientific views, claims to universality, and assumptions about the scientific state of another country masked what were in fact protective, nationalistic, and Eurocentric considerations (Adas 1989; Golinski 1998; Somsen 2008).

The investigation of the legal ownership of the fossils never led to a clear outcome or renewed discussions with Indonesia. In fact, the Dutch state kept Indonesia at bay. ${ }^{26}$ Robert Hotke, director general of cultural affairs at the Ministry of Culture, Recreation, and Social Work, who had been the chairman of the 1975 meeting in Indonesia, informed the civil servants who worked on the case that he wished for the fossils to stay in the Netherlands. ${ }^{27}$ A 1979 memorandum argued that the Dutch were very probably the rightful legal owner. This was followed by a note stating that the whole ownership discussion was a 'smokescreen' (uitvlucht) in any case, a clear indication that the Dutch were strategically delaying the issue. ${ }^{28}$ In another handwritten note in the archive, one civil servant writes to another that Vervoort should have kept quiet. ${ }^{29}$ By publicly showing his dismay, he had only added fuel to the fire.

The Netherlands have never handed back any fossils, but in the second half of the 1970s a victory for Indonesia came from an unexpected quarter. In 1975 and 1978, Teuku Jacob received the Ngandong skulls and the Mojokerto Child from his then Frankfurt-based mentor Von Koenigswald. These specimens were Homo erectus fossils excavated on Java in the 1930s, near the village of Ngandong and the town of Mojokerto. ${ }^{30}$ Von Koenigswald had always considered them his own property: he had taken care to protect them during the Japanese occupation of Java, and the fossils had travelled with him from Java to

25 Confidential letter from W. Vervoort, director of the Natural History Museum in Leiden, to R. Hotke, director-general of the Ministry of Culture, Recreation and Social Work, 2-3-1976, NA, Archive of the Ministry of Culture, Recreation, and Social Work, 2.27.19, 1425.

26 Letter from R. Hotke, director-general of the Ministry of Culture, Recreation and Social Work, to W. Vervoort, director of the Natural History Museum in Leiden, Leiden, 22-3-1976, NA, Archive of the Ministry of Culture, Recreation, and Social Work, 2.27.19, 1425 .

27 Memo by Th.J. Meijer to the head of the Main Section B of the Central Department Legislation and Legal Matters, 10-8-1977, NA, Archive of the Ministry of Culture, Recreation, and Social Work, 2.27.19, 1425.

28 D.G.C.Z. to W.A. Panis, 18-1-1979, NA, Archive of the Ministry of Culture, Recreation, and Social Work, 2.27.19, 1425.

29 Scribbled note to or from W.A. Panis, NA, Archive of the Ministry of Culture, Recreation, and Social Work, 2.27.19, 1425.

$30 \quad$ For the Ngandong skulls, see Huffman et al. 2010:1-6o. 
the United States, then to the Netherlands, and from there to the Senckenberg Forschungsinstitut und Naturmuseum Frankfurt (Senckenberg Research Institute and Natural History Museum Frankfurt) in Frankfurt, where he was invited to run a department devoted to palaeontology (Tobias 2010:268-9). An official argument for the return of these objects, and not of other skulls at Senckenberg, was that these specimens were dug up by the Netherlands East Indies Geological Survey and were 'protected and safeguarded with great personal risk during the time of the japanese [sic] and in the difficult period afterwards by Dr. and Mrs. von Koenigswald and some neutral friends.' ${ }^{31}$ This argument was obviously drawn up for the occasion, as it marked the difference between these skulls and others that Von Koenigswald did not return to Jacob and that he had excavated when he no longer worked for the Geological Survey.

\section{$5 \quad$ Java Man at the Museum in the Netherlands and Indonesia}

The Java Man fossils stayed in the Netherlands, and there have been no official claims or diplomatic discussions since the 1970s. This is probably due to a combination of factors: firstly, several objects, including (most but not all of) the Lombok treasure, were returned in the 1970s; and secondly, thanks to Von Koenigswald's donations and the excavation of the very complete skull of Sangiran 17 in 1969, Indonesia in fact already had a very good collection of hominid skulls. However, Indonesian academics such as the palaeontologist Iwan Kurniawan of the Bandung Museum of Geology have continued to advocate in the press for the fossils' 'homecoming. ${ }^{32}$

In Leiden the fossils remained out of sight of the public, the only objects in the collection to be kept in a safe. ${ }^{33}$ It was only in 1993 that the fossils were put on display, for the centennial exhibition to mark their discovery. ${ }^{34}$ The exhibition did not mention the ownership debate. However, in a reflection on the exhibition several years later, curator Mary Bouquet called the exhibition both

31 Official document noting that Teuku Jacob, on behalf on the Indonesian government, had received the Homo Modjokertensis skull, 13-9-1979. Signed by Jacob, Von Koenigswald, and two representatives of the Embassy of Indonesia, the Senckenberg Research Institute, and the Natural History Museum Frankfurt, Von Koenigswald Archive.

32 Destyan Handri Sujarwoko, 'Most pre-historic human fossils kept in Netherlands are Indonesian', Antara News, 30-4-2016.

33 'Resten “Java-Mens” uit Leidse museumkluis', Nieuwsblad van het Noorden, 26-3-1993.

34 Most newspapers said that the centennial exhibition celebrated a hundred years since the fossils were discovered; in fact 1893 was a hundred years after Dubois's telegram to the Netherlands which revealed the find to the Western world. 
an opportunity and an embarrassment, because the fossils were 'clearly out of context in the Netherlands' (Bouquet 1998:159).

Five years after this exhibition, and after more than fifty years in the museum's collection, the Java Man fossils were finally put on permanent public display: first in an open, green safe made by the Lips company, and later in a bulletproof glass case that curator of the Dubois collection John de Vos devised. It was placed among other fossils of extinct animals. As in many other natural history museums, 'nature' past and present was represented in a way that obscured its entanglement with the human world. At Naturalis, this meant that there was no place for stories about colonial collectors and their go-betweens, or about the political skirmishes between Indonesia and the Netherlands. Raden Saleh shows up in the museum's database as a finder of fossils but, unlike Martin or Dubois, has no specimens named after him. ${ }^{35}$ In the museum's 2003 catalogue, Dubois again takes centre stage as the sole finder of the skull in Trinil (Smolenaar 2003:13). In 2008, on the 15oth anniversary of Dubois's birth, Naturalis launched an exhibition called 'Dubois, Ontdekker van de Aapmens' (Dubois, discoverer of the ape-man). ${ }^{36}$ Again, the attention was focused on Dubois alone. When the museum reopened in 2019 after a major renovation, the fossils came back in the spotlight as the only original objects (together with an engraved shell) in a gallery that presents them as diamonds in a treasure chamber.

Java Man and Dubois also have a place in Indonesia's museums and their narrative of palaeontology. Near Trinil, where Java Man was found, a small museum with displays on palaeontology was officially opened in 1991, and there is a much larger museum in Sangiran, the site of many of the later Homo erectus fossil finds. This site became Unesco World Heritage in 1996 (Widianto and Simanjuntak 2010:105). A modest museum was created at the site in 1988, and a larger museum was opened by the president in 2011. The Sangiran museum, and since 2005 also the National Museum of Indonesia in Jakarta, does pay attention to Dubois but also celebrates Raden Saleh, who is seen as the 'founding father' of Indonesian palaeontology (bapak pionir paleontologi). ${ }^{37}$ The museum in Sangiran shows all the aspects of human evolution, includ-

35 Diverse fossils found by Raden Saleh around Solo between 1865 and 1867 are registered by the names of the European scientists who studied them: Elephas hysudrindicus Dubois, 1908 or Stegodon trigonocephalus Martin, 1887. See https://bioportal.naturalis.nl/ (accessed 3-2-2021).

$36 \quad$ The exhibition was held from 7 July until 6 October 2008.

37 'Raden Saleh: Pribumi Perintis Paleontologi', Geomagz, June 2013, https://geologi.esdm .go.id/assets/media/content/content-geomagz-vol-3-no-2-tahun-2013-.pdf (accessed 8-32021). 
ing casts of ancestor skulls, and its message suggests both pride in the fact that so many hominid fossils were found in this place and an awareness of their universal value. While the emphasis on Raden Saleh in both museums is an effort to move away from a solely Western perspective and a continuation of Yamin's nationalist framing of the fossils, Sangiran's narrative also fits neatly with Unesco's universalizing discourse (Smith 2006).

The above comparison shows that while both museums, in Leiden and in Sangiran, now emphasize the universal value of the fossils, Leiden pays most attention to the man who introduced them to the scientific world, and Indonesia to the locality that produced the fossils. Leiden thus overlooks the coloniality of Western knowledge-making practices, and both museums obscure the political sensitivity of the objects in the light of decolonization.

\section{6}

\section{Concluding Thoughts}

We have sketched a political biography of the human-fossil collection known as Java Man, taking a decolonial approach that challenged the discourse of colonial power and unearthed knowledge that has been pushed aside and buried. This biography has highlighted the importance of the knowledge of local informants and Indonesian specialized overseers in the making of scientific discoveries that were claimed by European men. This did not end with decolonization. The fossils' long contested political ownership and representations reveal the endurance of Eurocentric perspectives in the Netherlands, whereas Indonesia steered away from these by presenting a nationalized version of the place of Java Man in history. In Leiden the fossils symbolized Dutch state-ofthe-art colonial scholarship, whereas in Indonesia the hominid fossils were turned into national symbols that belonged to the culture and history of all Indonesia and had to return to within the physical boundaries of that country.

All these processes are of course linked with personal and institutional, colonial and national identity formation. Figures such as Dubois and Von Koenigswald built their reputation around these objects and also considered themselves the rightful owners; and in the postcolonial era Java Man was appropriated by nationalistic politics in Indonesia, and by a universalistic science discourse in the Netherlands - which was in fact similarly nationalistic and protective of its scientific reputation. Whereas in Indonesia the colonial past was banished to the margins and national achievements were emphasized, in the Netherlands imperialism continued for a long time to be considered 'efficient but judicious imperial management', with scientific benefits for all mankind (Gouda 1995). 
The current territorial approach in Indonesia is debatable, given that there is no direct historical connection between the hominids and present-day Indonesians. Equally debatable is the Dutch interpretation of the country's role in colonial Indonesia. Museums and the Java Man fossils are not unpolitical objects with universal meanings but the products of postcolonial histories, nationalist politics, and discourses of power. Natural history museums belong in decolonization debates as much as other museums with colonial collections. Critical reflection on the histories of these museums and the scientific disciplines they are associated with is a promising avenue for future scholarship and will also provide the necessary material for museums to draw on in their displays and presentation and in the formulation of their viewpoints on ethical issues such as repatriation.

\section{References}

\section{Unpublished Sources}

Nationaal Archief (National Archives of the Netherlands), The Hague

- Archief van het Ministerie van Koloniën en opvolgers (Archive of the Ministry of Colonies and its Successors) 2.10.54

- Archieven van de Ministeries voor Algemeene Oorlogvoering van het Koninkrijk, en van Algemene Zaken (Az): Kabinet van de minister-president (Archive of the Minister of War and of General Affairs, Cabinet of the Prime Minister) 2.03.01

- Archief van het Ministerie van Cultuur, Recreatie en Maatschappelijk Werk (Archive of the Ministry of Culture, Recreation and Social Work) 2.27.19

Senckenberg Forschungsinstitut und Naturmuseum Frankfurt (Senckenberg Research Institute and Natural History Museum Frankfurt)

- Von Koenigswald Archive

\section{Published Sources}

Adas, M. (1989). Machines as the measure of men: Science, technology and ideologies of Western dominance. Ithaca: Cornell University Press.

Albers, C.H.A. and J. de Vos (2009). Through Eugène Dubois' eyes: Stills of a turbulent life. Leiden: Brill.

Alberti, S.J.M.M. (2005). 'Objects and the museum', Isis 96-4:559-71.

Appadurai, A. (1986). The social life of things: Commodities in cultural perspective. Cambridge: Cambridge University Press.

Baber, F. (1996). Science of empire: Scientific knowledge, civilization and colonial rule in India. Albany: State University of New York Press. 
Barkan, E. (2002). 'Amending historical injustices: The restitution of cultural property', in: Elazar Barkan and Ronald Bush (eds), Claiming the stones, naming the bones, pp. 16-5o. Los Angeles: Getty Research Institute.

Beurden, J. van (2017). Treasures in trusted hands: Negotiating the future of colonial cultural objects. Leiden: Sidestone Press.

Bloembergen, M. and M. Eickhoff (2011). 'Conserving the past, mobilizing the Indonesian future. Archaeological sites, regime change and heritage politics in Indonesia in the 195os', Bijdragen tot de Taal-, Land- en Volkenkunde 167-4:405-36.

Bloembergen, M. and M. Eickhoff (2015). 'The colonial archaeological hero reconsidered: Postcolonial perspectives on the "discovery" of pre-historic Indonesia', in: Gisela Eberhardt and Fabian Link (eds), Historiographical approaches to past archaeological research, pp. 133-64. Berlin: Topoi.

Bloembergen, M. and M. Eickhoff (2020). The politics of heritage in Indonesia: A cultural history. Cambridge: Cambridge University Press.

Bouquet, M. (1998). 'Strangers in paradise. An encounter with Fossil Man at the Dutch Museum of Natural History', in: Sharon Macdonald (ed.), The politics of display: Museums, science, culture, pp. 159-72. London: Routledge.

Brown, J. (1996). 'Biogeography and empire', in: N. Jardine, J.A. Secord and E.C. Spary (eds), Cultures of natural history, pp. 305-21. Cambridge: Cambridge University Press.

Carnall, M., J. Ashby and C. Ross (2013). 'Natural history museums as provocateurs for dialogue and debate', Museum Management and Curatorship 28:55-71.

Chambers, D.W. and R. Gillespie (2000). 'Locality in the history of science: Colonial science, technoscience, and indigenous knowledge', Osiris 15:221-40.

Cohn, B.S. (1996). Colonialism and its forms of knowledge. Princeton: Princeton University Press.

Dahlbom, T. (2009). 'Matter of fact: Biographies of zoological specimens', Museum History Journal 2-1:51-72.

Das, S. and M. Lowe (2018). 'Nature read in black and white: Decolonial approaches to interpreting natural history collections', Journal of Natural Science Collections 6:414.

Dirks, N.B. (1996). 'Foreword', in: L.B.S. Cohn (ed.), Colonialism and its forms of knowledge: The British in India, pp. ix-xvii. Princeton: Princeton University Press.

Dirks, N.B. (2001). Castes of mind: Colonialism and the making of modern India. Princeton: Princeton University Press.

Drayton, R. (2000). Nature's government: Science, imperial Britain, and the 'improvement' of the world. New Haven, CT: Yale University Press.

Drieënhuizen, C. (2018). 'Mirrors of time and agents of action. Indonesia's claimed cultural objects and decolonisation, 1947-1978', BMGN. Low Countries Historical Review 133-2:91-104. 
Dubois, E. (1889). 'Over de wenschelijkheid van een onderzoek naar de diluviale fauna van Ned. Indië, in het bijzonder van Sumatra', Natuurkundig Tijdschrift voor Nederlandsch-Indië 48:148-65.

Geer, A. van der, M. Dermitzakis and J. de Vos (2008). 'Fossil folklore from India: The Siwalik hills and the Mahâbhârata', Folklore 119:71-92.

Golinski, J. (1998). Making natural knowledge: Constructivism and the history of science. Cambridge: Cambridge University Press.

Gosden C. and Y. Marshall (1999). 'The cultural biography of objects', World Archaeology 31-2:169-78.

Gouda, F. (1995). Dutch culture overseas: Colonial practice in the Netherlands Indies, 1900-1942. Amsterdam: Amsterdam University Press.

Greenfield, J. (2007). The return of cultural treasures. Cambridge: Cambridge University Press.

Handini, Retno (2015). 'Balung Buto dalam persepsi masyarakat Sangiran: Antara mitos dan fakta', Kalpataru. Majalah Arkeologi 24:61-72.

Haraway, D. (1984). 'Teddy bear patriarchy: Taxidermy in the Garden of Eden, New York City, 19o8-1936', Social Text 11:20-64.

Huffman, O.F., P. Shipman, C. Hertler, J. de Vos, and F. Aziz (2005). 'Historical evidence of the 1936 Mojokerto skull discovery, East Java', Journal of Human Evolution 48:32163.

Huffman, Frank, J. de Vos, A.W. Berkhout, and F. Aziz (2010). 'Provenience reassessment of the 1931-1933 Ngandong Homo erectus (Java). Confirmation of the bone-bed origin reported by the discoverers', PaleoAnthropology:1-6o.

Jacob, T. (1973). 'Palaeoanthropological discoveries in Indonesia with special reference to the finds of the last two decades', Journal of Human Evolution 2-6:473-78.

Koenigswald, G.H.R. von (1956). Speurtocht in de prehistorie. Ontmoetingen met onze voorouders. Transl. by J. Vrijman. Amsterdam: De Spieghel.

Kopytoff, I. (1986). 'The cultural biography of things: commoditization as process', in: A. Appadurai (ed.), The social life of things: Commodities in cultural perspective, pp. 64-91. Cambridge: Cambridge University Press.

Kraus, W. (2012). Raden Saleh: The beginning of modern Indonesian painting. [Jakarta]: Goethe-Institut Indonesien.

Kroef, J. van der (1958). 'On the writing of Indonesian history', Pacific Affairs 21:352-71.

Legêne, S. (1998). 'From brooms to Obeah and back: Fetish conversion and border crossings in nineteenth-century Suriname', in: P. Spyer (ed.), Border fetishisms: Material objects in unstable places, pp. 35-59. New York and London: Routledge.

Legêne S., and E. Postel-Coster (2000). 'Isn’t it all culture? Culture and Dutch development policy in the post-colonial period', in: J.A. Nekkers and P.A.M. Malcontent (eds), Fiftyyears of Dutch development cooperation, 1949-1999, pp. 271-88. The Hague: Sdu. 
Lyons, C.L. (2002). 'Objects and identities: Claiming and reclaiming the past', in: Elazar Barkan and Ronald Bush (eds), Claiming the stones, naming the bones: Cultural property and the negotiation of national and ethnic identity, pp. 116-37. Los Angeles: Getty Research Institute.

Montero Sobrevilla, I. (2018). 'Indigenous naturalists', in: H.A. Curry, N. Jardine, J.A. Secord and E.C. Spary (eds), Worlds of natural history, pp. 112-30. Cambridge: Cambridge University Press.

Musonda, F. (2013). 'Decolonising the Broken Hill Skull: Cultural loss and a pathway to Zambian archaeological sovereignty', African Archaeological Review 30:195-220.

Noer, D. (1979). 'Yamin and Hamka: Two routes to an Indonesian identity', in: Anthony Reid and David Marr (eds), Perceptions of the past in Southeast Asia, pp. 249-62. Singapore: Heinemann.

Poerwolelono, Raden Mas Arjo (pseud. of Raden Mas Toemenggoeng Arjo Soerio Tjondronegoro) (2013). Op reis met een Javaanse edelman: Een levendig portret van koloniaal Java in de negentiende eeuw (1860-1875); De reizen van Radèn Mas Arjo Poerwolelono. Translated and edited by J. Bosnak, F. Koot, and R.A.G. Soekatno, based on the second edition of Tjondronegoro's original work (1877). Zutphen: Walburg Pers. [First edition: 1865 and 1866 .]

Pols, H. (2009). 'European physicians and botanists, indigenous herbal medicine in the Dutch East Indies, and colonial networks of mediation', East Asian Science, Technology and Society 3:173-208.

Pols, H. (2018). Nurturing Indonesia. Medicine and decolonisation in the Dutch East Indies. Cambridge: Cambridge University Press.

Pratt, M.L. (1992). Imperial eyes: Travel writing and transculturation. London: Routledge. Quijano, Aníbal (2007). 'Coloniality and modernity/rationality', Cultural Studies 21:16878.

Raden Saleh (1867). 'Over fossiele beenderen van den Pandan', Natuurkundig Tijdschrift voor Nederlandsch-Indië 29:422-3, 426-9, 433-7, 448-51 and 455-9.

Schmalzer, S. (2008). The people's Peking Man: Popular science and human identity in twentieth-century China. Chicago: University of Chicago Press.

Schulte Nordholt, H. (2004). 'De-colonising Indonesian historiography', paper presented at the Centre for East and South-East Asian Studies public lecture series 'Focus Asia', Lund University, 25-27 May.

Schumaker, L. (2001). Africanizing anthropology: Fieldwork, networks, and the making of cultural knowledge in Central Africa. Durham: Duke University Press.

Scott, C. (2017). 'Renewing the "special relationship" and rethinking the return of cultural property: The Netherlands and Indonesia, 1949-79', Journal of Contemporary History 52:646-68.

Scott, C. (2019). Cultural diplomacy and the heritage of Empire. Negotiating post-colonial returns. New York, NY: Routledge. 
Shipman, P. (2001). The man who found the missing link: Eugène Dubois and his lifelong quest to prove Darwin right. New York: Simon and Schuster.

Smith L. (2006). Uses of heritage, London, New York: Routledge.

Smolenaar, E. (2003). Museumgids Naturalis, Leiden: Naturalis.

Somsen, G.J. (2008). 'A history of universalism: Conceptions of the internationality of science from the enlightenment to the Cold War', Minerva 46:361-79.

Staniforth, A. (2009). 'Returning Zinj: Curating human origins in twentieth-century Tanzania', Journal of East African Studies 3:153-73.

Sulistyanto, Bambang (2003). Balung buto: Warisan budaya dunia dalam perspektif masyarakat Sangiran. Yogyakarta: Kunci Ilmu.

Sulistyanto, Bambang (2009). 'Warisan dunia Situs Sangiran. Persepsi menurut penduduk Sangiran', Wacana 11: 57-80.

Sysling, F. (2016). Racial science and human diversity in colonial Indonesia. Singapore: Singapore University Press.

Theunissen, B. (1989). Eugène Dubois and the ape-man from Java. Boston: Kluwer Academic.

Tobias, P.V. (2010). 'Hominid fossils as universal and national cultural heritage: An essay on past and present attitudes towards the ownership of hominid fossils and the questions of repatriation', in: M. Montagnari Kokelj, M. Budinich, and C. Tuniz (eds), Science for cultural heritage. Technological innovation and case studies in marine and land archaeology in the Adriatic region and inland, pp. 258-79. Singapore: World Scientific Publishing.

Wagoner, P.B. (2003). 'Precolonial intellectuals and the production of colonial knowledge', Comparative Studies in Society and History 43:783-6.

Watson-Verran, Helen and David Turnbull (1995). 'Science and other indigenous knowledge systems', in: Sheila Jasanoff, Gerald E. Markle, James C. Petersen and Trevor Pinch (eds), Handbook of science and technologystudies, pp. 115-39. Thousand Oaks, CA: Sage Publications.

Widianto, H. and T. Simanjuntak (2010). Sangiran answering the world. Sragen, Indonesia: Ministry of Culture and Tourism.

Wood, M. (2005). Official history in modern Indonesia: New Order perceptions and counterviews. Leiden: Brill. 